\title{
Analysis of Factors Influencing Korea's Air Trade with China
}

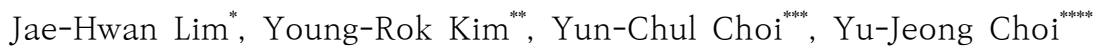

\begin{abstract}
This study aims to identify the representative factors affecting the air trade between the two countries over the past 20 years, targeting China, Korea's largest trading partner for air transport. In the analysis, the two countries' GDP, GDP per capita, and tariff rates, as well as exchange rates, international oil prices, and FTAs were used as variables. For the analysis method, OLS multiple regression analysis was performed, and each was analyzed by dividing the export amount, import amount, and trade amount. As a result of the analysis, China's GDP and Korea's GDP per capita showed a positive (+) direction, an increase in the exchange rate resulted in an increase in the amount of trade, and an increase in the tariff rate resulted in a decrease in the amount of trade. Whether the FTA was concluded or not acted as a factor in increasing the amount of trade between the two countries.
\end{abstract}

Key Words : Largest Trading Partner(최대 교역국), Affect Factor(영향 요인), OLS Multiple Regression Analysis(OLS 다중회귀분석), Exchange Rate Rise(환율 상승), Tariff Rate Rise(관세율 상승)

\section{INTRODUCTION}

Despite the soaring cases of COVID-19, South Korea's share in the global export market continues to rise. Most can be attributed to the increase in exports to China, as China is South Korea's largest trading partner, and the trade surplus through trade with China has become an important factor in South Korea's economic development. When the diplomatic

Received: 09. Aug. 2021, Accepted: 17. Aug. 2021

* Professor, Department of Aviation Management \& Logistics, Catholic Kwandong University

** Professor, Department of Aeronautical Science \& Flight Operation, Silla University

Corresponding Author E-mail : atc30th@hanmail.net Corresponding Author address : Room 226, Future Aviation Convergence Building, Shilla University, Busan, Korea

**** Professor, Department of Aviation, Hanseo University

***** Team Leader, Planning and Coordination Office, Korea Institute for National Unification ties were established between South Korea and China in 1992, trade between the two countries was only US\$6.3 billion, but as of 2019, it was US $\$ 243.4$ billion, a 40-fold increase. In addition, increased trade to China, which has a relatively high economic growth rate compared to the US and Japan, where import demand continues to decrease due to the recent global economic downturn, and a member of WTO, is an important part of South Korea's continued economic growth. However, China has been pushing out export products made by neighboring countries, including South Korea, from the major markets such as the US and Japan with its price competitiveness, gradually increasing its market share. Therefore, this study analyzes factors affecting air trade with China by focusing on the air transportation sector used for transporting high value-added goods among South Korea's trade with China, and further explore strategies to continuously expand air trade. The 
target period of this study is the last 20 years from 2000 to 2019, and we analyzed the factors affecting air transport exports, imports, and trades, respectively, between the two countries. The independent variables we used were the exchange rate, oil price, and tariff rate data, including the gross domestic product (GDP) and GDP per capita of South Korea and China. As the analysis method, an Ordinary Least Squares (OLS) multi-regression analysis was performed, and the data were composed as panel data to increase the reliability of the analysis results.

This paper is organized in the following order. First, we examine existing literature on studies for trade with China and analyze the status of the air transport trade in detail. Then, we explain the variables and analysis method used in this study and produce analysis results. Lastly, we summarize the study results and provide conclusions.

\section{RELATED WORK AND CURRENT STATUS}

\subsection{Related Work}

Most studies on trade policies between South Korea and China are generally focused on the establishment of policies or strategies for the vitalization of trades, rather than focusing on air transport. In the air transport field, some recent studies have investigated the increase in demand for the transport of advanced highvalue-added products, including semiconductors, and examined the linkage between airports and marine transport to secure cargo volumes. First, Lee (2017) analyzed the effect of the Korea-China FTA (free trade agreement) on the air transport sector and proposed the aviation policy direction of South Korea. The study forecasted that the Korea-China FTA will expand the demand for air logistics and argued to build a support mechanism for strengthening the competitiveness of South Korea's air trans- port industry and airports. Kim (2007), on the other hand, analyzed the effect of the Chinese economy on the sea and air transport volumes and suggested a method of vitalizing hybrid air-sea logistics. According to the study results, it was required to build a new transport mechanism because of the growth of the Chinese economy and the deterioration of the structure of increasing sea and air volumes in South Korea. Furthermore, he suggested expanding the linkage between ports and airports as a way of vitalizing hybrid air-sea transport. Choi (2010) analyzed South Korea's trade structure with China after the financial crisis. Noting that the pace of import substitution of intermediate goods had been quickly increasing due to the advancement of Chinese industry, he suggested to reduce the import and export dependence on China in the medium to long term and pursue high technology and high value-added of export products to China, such as semiconductors, which were major products for air transport. In a study analyzing the trade relations between South Korea and China based on the foreign trade policies of China, Seo and Kim (2008) mentioned the importance of expanding the exports of technology-intensive high-valueadded products along with ongoing efforts for balancing trades by reducing the excessive dependency on exports to China for each product as a way of vitalizing South KoreaChina trades. Han (2019) analyzed the characteristics and countermeasures of trade with China for South Korea. As a result, he presented problems caused by deteriorated foreign trades of the Chinese economy in the face of gradually increasing the export dependence on China and proposed strategic measures. In the study, considering the changes in China's investment environment and structure in terms of establishing strategies for penetrating China, he argued that strategic measures were needed, which should be in line with the policies implemented by China while being differen- 
tiated from those of other competing countries based on the industries with comparative advantage, including high-value-added products.

\subsection{Status of Air Trade with China}

First, as shown in Table 1, South Korea's total air cargo export has been continuously trending upward in the last ten years, except in 2019, in which it was affected by the global economic crisis. Particularly, in 2018, an annual record of exceeding US $\$ 200$ billion was achieved for the first time. The air carbo export to China has been also trending upward continuously except in 2016 and 2019. The exports to China react to external factors more sensitively, showing the characteristic of increasing/decreasing in a larger range than the changes in the total export amount.

Next, as shown in Table 2, the total air cargo import of South Korea has been generally growing in the last ten years. In 2019, however, it recorded US\$137.9 billion, down about 3.5\% from the previous year. In the case of air cargo

Table 1. Status of air cargo exports

(Unit: US\$100 million, \%)

\begin{tabular}{c|c|c}
\hline Year & $\begin{array}{c}\text { Total air cargo } \\
\text { export }\end{array}$ & $\begin{array}{c}\text { Air cargo export } \\
\text { to China }\end{array}$ \\
\hline 2019 & $1,643(-18.5)$ & $533(-22.6)$ \\
\hline 2018 & $2,015(15.2)$ & $689(22.7)$ \\
\hline 2017 & $1,750(30.3)$ & $561(40.2)$ \\
\hline 2016 & $1,343(-3.3)$ & $400(-15.5)$ \\
\hline 2015 & $1,389(1.6)$ & $474(3.0)$ \\
\hline 2014 & $1,368(3.6)$ & $460(4.7)$ \\
\hline 2013 & $1,320(11.6)$ & $439(22.3)$ \\
\hline 2012 & $1,183(1.5)$ & $359(17.3)$ \\
\hline 2011 & $1,166(1.6)$ & $306(-2.4)$ \\
\hline 2010 & $1,148(27.0)$ & $314(41.5)$ \\
\hline
\end{tabular}

Source: The Korea International Trade Association.

Note: The number in ( ) is the increase/decrease rate compared to the previous year.
Table 2. Status of air cargo imports

(Unit: US\$100 million, \%)

\begin{tabular}{c|c|c}
\hline Year & $\begin{array}{c}\text { Total air cargo } \\
\text { import }\end{array}$ & $\begin{array}{c}\text { Air cargo import } \\
\text { from China }\end{array}$ \\
\hline 2019 & $1,379(-3.5)$ & $313(0.2)$ \\
\hline 2018 & $1,429(4.8)$ & $312(10.9)$ \\
\hline 2017 & $1,363(18.7)$ & $281(15.9)$ \\
\hline 2016 & $1,149(-0.8)$ & $243(-9.1)$ \\
\hline 2015 & $1,157(2.2)$ & $267(12.1)$ \\
\hline 2014 & $1,133(4.5)$ & $238(7.4)$ \\
\hline 2013 & $1,083(4.5)$ & $222(8.3)$ \\
\hline 2012 & $1,037(-5.9)$ & $205(-9.7)$ \\
\hline 2011 & $1,101(10.1)$ & $227(16.4)$ \\
\hline 2010 & $1,000(31.5)$ & $195(37.4)$ \\
\hline
\end{tabular}

Source: The Korea International Trade Association.

Note: The number in ( ) is the increase/decrease rate compared to the previous year.

imports from China, the increase/decrease rate is slightly larger than that of the total import amount, but when compared to the export amount, it shows a slow increasing/decreasing trend without large deviations.

Upon examination of export amounts to China, we find that the amounts of semiconductors, computers, and wireless communication devices, which are high-value-added products, are absolutely large, as shown in Table 3. Although the amounts of these three items have been slightly decreasing in the last three years, since their proportions in the top ten items are still large, the predominance of certain items in exports has been continuing.

As shown in Table 4, the analysis on the amounts of imports from China reveals that semiconductors, wireless communication devices, and computers, which are high-value-added products, also account for the absolute majority in the amounts, as was the case in export products. In the last three years, the amounts of these three items have been continuously increasing, and their proportions among the 
Table 3. Status of air cargo export by item (Unit: US\$100 million)

\begin{tabular}{|c|c|c|c|c|}
\hline \multirow{2}{*}{ Rank } & \multirow{2}{*}{ Item } & \multicolumn{3}{|c|}{ Year } \\
\hline & & 2019 & 2018 & 2017 \\
\hline 1 & Semiconductors & 367 & 515 & 387 \\
\hline 2 & Computers & 21 & 28 & 22 \\
\hline 3 & $\begin{array}{c}\text { Wireless } \\
\text { communication } \\
\text { devices }\end{array}$ & 21 & 27 & 42 \\
\hline 4 & Optical devices & 20 & 18 & 13 \\
\hline 5 & Machine parts & 17 & 17 & 19 \\
\hline 6 & $\begin{array}{l}\text { Semiconductor } \\
\text { manufacturing } \\
\text { equipment }\end{array}$ & 16 & 9 & 7 \\
\hline 7 & $\begin{array}{l}\text { Flat panel displays } \\
\text { and sensors }\end{array}$ & 9 & 10 & 16 \\
\hline 8 & Plastic products & 5 & 5 & 4 \\
\hline 9 & $\begin{array}{l}\text { Measurement, } \\
\text { control, and } \\
\text { analysis devices }\end{array}$ & 5 & 6 & 5 \\
\hline 10 & $\begin{array}{l}\text { Soaps, toothpaste, } \\
\text { and cosmetics }\end{array}$ & 4 & 4 & 3 \\
\hline
\end{tabular}

Source: The Korea International Trade Association.

Note: Top ten items of export amounts in 2019 (based on MTI 3 unit).

Table 4. Status of air cargo import by item (Unit: US\$100 million)

\begin{tabular}{c|c|c|c|c}
\hline \multirow{2}{*}{ Rank } & Item & \multicolumn{3}{|c}{ Year } \\
\cline { 3 - 5 } & & 2019 & 2018 & 2017 \\
\hline 1 & Semiconductors & 169 & 151 & 123 \\
\hline 3 & $\begin{array}{c}\text { Wireless } \\
\text { communication } \\
\text { devices }\end{array}$ & 41 & 44 & 48 \\
\hline 4 & Computers & 31 & 43 & 38 \\
\hline 5 & $\begin{array}{c}\text { Machine parts } \\
\text { communication } \\
\text { devices }\end{array}$ & 7 & 7 & 8 \\
\hline 6 & $\begin{array}{c}\text { Flat panel displays } \\
\text { and sensors }\end{array}$ & 4 & 6 & 9 \\
\hline 7 & $\begin{array}{c}\text { Measurement, } \\
\text { control, and } \\
\text { analysis devices }\end{array}$ & 4 & 4 & 3 \\
\hline 10 & $\begin{array}{c}\text { Industrial electric } \\
\text { devices }\end{array}$ & 4 & 5 & 6 \\
\hline Passive & 4 & 4 & 3 \\
\hline components & Optical devices & 3 & 3 & 4 \\
\hline
\end{tabular}

Source: The Korea International Trade Association.

Note: Top ten items of import amounts in 2019 (based on MTI 3 unit). top ten items have been also continuously increasing. Furthermore, the predominance of certain products in the export amounts is also shown as a characteristic feature in the import products.

\section{VARIABLE AND ANALYSIS METHOD}

As shown in Table 5, we used the released data of the Korea International Trade Association (KITA) for the data of export amount, import amount, and trade amount, which is their sum, for the trade with China, which were dependent variables. Data from the World Bank were used for independent variables such as GDP and GDP per capita, and data from the OECD were used for the exchange rate and international oil price data. The WTO data were

Table 5. Variables and sources

\begin{tabular}{|c|c|c|c|}
\hline Type & Variable & Description & Source \\
\hline $\begin{array}{c}\text { Dependent } \\
\text { variable }\end{array}$ & $\begin{array}{l}\text { Trade } \\
\text { amount }\end{array}$ & $\begin{array}{l}\text { Export } \\
\text { amount, } \\
\text { import } \\
\text { amount, } \\
\text { trade } \\
\text { amount }\end{array}$ & KITA \\
\hline \multirow{5}{*}{$\begin{array}{c}\text { Independent } \\
\text { variable }\end{array}$} & GDP & $\begin{array}{c}\text { Gross } \\
\text { domestic } \\
\text { product }\end{array}$ & World Bank \\
\hline & PERGDP & $\begin{array}{l}\text { GDP per } \\
\text { capita }\end{array}$ & World Bank \\
\hline & $\begin{array}{l}\text { Exchange } \\
\text { rate }\end{array}$ & $\begin{array}{l}\text { Exchange } \\
\text { rate of } \\
\text { currencies }\end{array}$ & OECD \\
\hline & $\begin{array}{c}\text { International } \\
\text { oil price }\end{array}$ & $\begin{array}{c}\text { International } \\
\text { oil price }\end{array}$ & OECD \\
\hline & Tariff rate & $\begin{array}{l}\text { Average } \\
\text { tariff rate } \\
\text { of each } \\
\text { country }\end{array}$ & WTO \\
\hline $\begin{array}{l}\text { Dummy } \\
\text { variable }\end{array}$ & FTA & $\begin{array}{l}\text { Whether the } \\
\text { FTA has } \\
\text { been made } \\
\text { or not }\end{array}$ & MoTIE \\
\hline
\end{tabular}


used for the tariff rates, and data from the South Korean Ministry of Trade, Industry and Energy (MoTIE) were used for the status of entering FTA (whether the FTA has been made or not), which was a dummy variable.

Since the GDP amount, among the independent variables, is an indicator that shows the total economic size of a country, it is included in the variables. We can safely assume that as the GDP amount increases, the trade between nations will also increase. The GDP per capita was selected as a variable in this study because the income level can affect the trade amount between countries, and we determined that the higher the GDP per capita, the higher the air trade amount. Since the exchange rate refers to the exchange rate of currencies between countries, the exchange rate fluctuations can affect the country's economy as a whole. We included the international oil price in the variables, thinking that it will affect the increase/decrease of trade costs since its increase/ decrease will result in an increase/decrease in transportation costs, including freight costs. Furthermore, the tariff rate is a tax imposed on trading products in each country, and it was included as an important variable because its increase/decrease may lead to an increase/ decrease in the product price. The status of entering FTA was also included in the variables because it can affect the overall import and export policies between countries.

The analysis method used in this study is an OLS multi-regression analysis. The OLS multiregression analysis can improve the analysis results by simultaneously applying multiple independent variables that affect the dependent variables. Furthermore, by additionally adopting multiple independent variables, it can reduce the value of the error term and remove the bias compared to regular regression analysis. Hence, it was applied as the analysis method. The data were composed in a panel format to increase the reliability of the analysis results.
IV. ANALYSIS RESULTS

Table 6 summarizes the results of analyzing the factors affecting the air trade with China. The OLS multi-regression analysis was performed by dividing the export amounts, import amounts, and trade amounts. In the analysis results, the export amount showed a positive $(+)$ correlation with China's GDP and South Korea's GDP per capita. On the other hand, the exchange rate and the international oil price showed negative $(+)$ results, respectively. In the case of tariffs, China's tariff rate showed a positive (+) result, and the FTA status, which was expected to show an increase, showed a negative (-) result. In the case of import amounts, China's GDP showed a negative (-) result while South Korea's GDP showed a positive $(+)$ result, and the GDP per capita of both countries showed positive $(+)$ results, respectively. The exchange rate, international oil price, and the FTA status showed positive (+) results, respectively, unlike the case of export amounts. In the case of tariffs, both countries showed negative results, respectively. The analysis results of the trade amounts were generally similar to those of the export amounts. This was largely due to the effect of the export

Table 6. Analysis results of air trade with China

\begin{tabular}{c|c|c|c}
\hline Variable & $\begin{array}{c}\text { Export } \\
\text { amount }\end{array}$ & $\begin{array}{c}\text { Import } \\
\text { amount }\end{array}$ & $\begin{array}{c}\text { Trade } \\
\text { amount }\end{array}$ \\
\hline ln_cgdp & $(+)$ & $(-)$ & $(+)$ \\
\hline ln_cpergdp & $(-)$ & $(+)$ & $(-)$ \\
\hline ln_kgdp & $(-)$ & $(+)$ & $(-)$ \\
\hline ln_kpergdp & $(+)$ & $(+)$ & $(+)$ \\
\hline ln_exchanges & $(-)$ & $(+)$ & $(+)$ \\
\hline ln_oil & $(-)$ & $(+)$ & $(-)$ \\
\hline ln_ctariff & $(+)$ & $(-)$ & $(+)$ \\
\hline ln_ktariff & $(-)$ & $(-)$ & $(-)$ \\
\hline FTA & $(-)$ & $(+)$ & $(+)$ \\
\hline
\end{tabular}


amount that accounted for $65 \%$ of the trade amount. When examined in detail, China's GDP and South Korea's GDP per capita showed positive (+) results, respectively. In the case of the effects of tariffs on the trade amount, China's tariff rate showed a positive $(+)$ result whereas South Korea's tariff rate showed a negative (-) result. Lastly, the FTA status showed a positive (+) result.

\section{CONCLUSION}

In this study, we conducted OLS multi-regression analysis on air transport export amount, import amount, and trade amount over 20 years from 2000 to 2019 to investigate the factors affecting air trades targeting China, the largest air transport trading country of South Korea. In the analysis, both countries' GDP, GDP per capita, and tariff rate were used. Moreover, the exchange rate, international oil price, and the FTA status (whether FTA has been entered or not) were also used as variables. In the analysis results, China's GDP and South Korea's GDP per capita showed a positive $(+)$ result, respectively. This implies that (1) the growth of China's GDP, i.e., the growth of China's economy affected the increase in the export of products that serve as intermediate materials of final products, such as semiconductors, which were major air trade products; (2) the increase in South Korea's GDP per capita, i.e., personal consumption power was a factor that affected the increase in the import demand in air trade. When the exchange rate increased, it was a factor that increased the trade amount through the effect of relatively decreasing the import product prices. When the tariff rate was increased, it led to price increases of the customcleared products, causing a decrease in the trade amounts of South Korea. Since the FTA can be associated with national policies, it serves as a factor that increases the trade amounts.

However, the limited analysis in this study cannot clearly identify the factors affecting air trade with China, and continuous research is need for this in the future. In particular, since factors that cannot be converted into numerical values, such as national sentiment or cultural factors which were not reflected in the analysis, can have significant impacts on trades between the two countries, we should conduct the research continuously using specific data for this.

\section{References}

1. Choi, B. C., "The analysis of Korea's trade structure to China after financial crisis", The Journal of International Trade \& Commerce, 6(4), 2010, pp.31-56.

2. Han, D. G., "The characteristics and countermeasures of direct investment and trade of South Korea in China”, The Journal of International Trade \& Commerce, 15(3), 2019, pp.311-333.

3. Kim, C. B., "China effect and sea/air intermodel transport in Korea", Journal of Korea Port Economic Association, 23(2), 2007, pp. $25-40$

4. Lee, K. B., "The effect on air transport sector by Korea-China FTA and aviation policy direction of Korea”, Korea Society of Air \& Space Law and Policy, 32(1), 2017, pp.83138.

5. Seo, K. S. and Kim, J. S., "A study on the activation of South Korea and China trade regarding China's foreign trade policy changes", Korean Business Review, 1(2), 2008, pp.261284. 